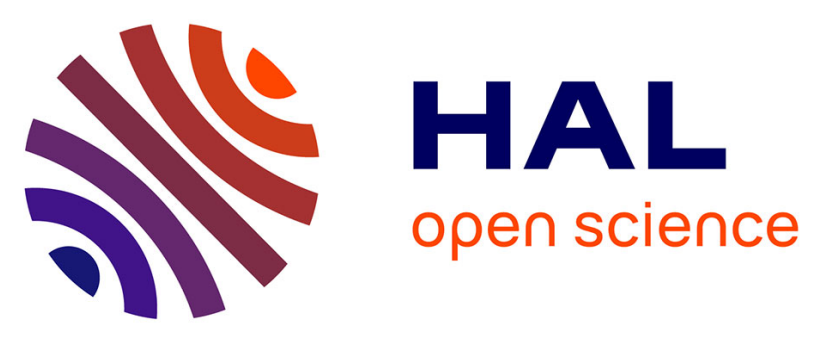

\title{
A pulmonary embolism (PE) with an unexpected intracardiac mass but without shock: Should we use thrombolytic therapy? About a case of a 88 year old man with suspicion of $\mathrm{PE}$ \\ Sylvain Aguilhon, d'Arcy Vandenberghe, François Roubille
}

\section{To cite this version:}

Sylvain Aguilhon, d'Arcy Vandenberghe, François Roubille. A pulmonary embolism (PE) with an unexpected intracardiac mass but without shock: Should we use thrombolytic therapy? About a case of a 88 year old man with suspicion of PE. International Journal of Cardiology, 2017, 227, pp.892 893. 10.1016/j.ijcard.2016.11.184. hal-01823053

\section{HAL Id: hal-01823053 \\ https://hal.umontpellier.fr/hal-01823053}

Submitted on 10 Dec 2019

HAL is a multi-disciplinary open access archive for the deposit and dissemination of scientific research documents, whether they are published or not. The documents may come from teaching and research institutions in France or abroad, or from public or private research centers.
L'archive ouverte pluridisciplinaire HAL, est destinée au dépôt et à la diffusion de documents scientifiques de niveau recherche, publiés ou non, émanant des établissements d'enseignement et de recherche français ou étrangers, des laboratoires publics ou privés. 


\title{
A pulmonary embolism (PE) with an unexpected intracardiac mass but without shock: Should we use thrombolytic therapy? About a case of a 88 year old man with suspicion of $\mathrm{PE}$
}

\author{
Sylvain Aguilhon a,*, D'Arcy Vandenberghe ${ }^{\mathrm{a}}$, François Roubille ${ }^{\mathrm{a}, \mathrm{b}}$ \\ a Cardiology Department, Hôpital Arnaud de Villeneuve, CHU de Montpellier, UFR de Médecine, Université Montpellier 1, 371, Avenue du Doyen Gaston Giraud, 34295 Montpellier Cedex 05, France \\ ${ }^{\mathrm{b}}$ PhyMedExp, University of Montpellier, INSERM U1046, CNRS UMR 9214, 34295 Montpellier Cedex 5, France
}

\section{Clinical case}

A 88 year old man was admitted for dyspnea. His main past medical histories were a chronic renal insufficiency of diabetic origin, a chronic inflammatory rheumatism, an ischemic stroke, an arterial hypertension.
His treatment included daily bisoprolol $2.5 \mathrm{mg}$, aspirin $75 \mathrm{mg}$, amlodipine $5 \mathrm{mg}$, trinitrine $15 \mathrm{mg} / 24 \mathrm{~h}$, prednisone $5 \mathrm{mg}$, sertraline $75 \mathrm{mg}$, furosemide $20 \mathrm{mg}$. On admission, hemodynamic was uncertain with a transitory arterial low blood pressure (SBP $<90 \mathrm{mmHg}$ ). Physical examination revealed right heart failure. The biology showed a systemic inflammatory syndrome with $209 \mathrm{mg} / \mathrm{L}$ of C-reactive protein (normal value $<5$ ). The cardiac markers were elevated: NT-proBNP to 27,000 (normal value $<400$ ), and a high-sentitive troponine-Tat 320 controlled to 340 (normal value $<14 \mathrm{ng} / \mathrm{L}$ ). There was an acute renal insufficiency with $280 \mu \mathrm{mol}$ of creatinin against 200 (basis). The chest X-ray found a diffuse vascular overload without real identified infectious focus. A treatment with diuretic and antibiotherapy was started and the patient was transferred in a service of internal medicine. Unfortunately, the hemodynamic deteriorated quickly with an arterial hypotension. A

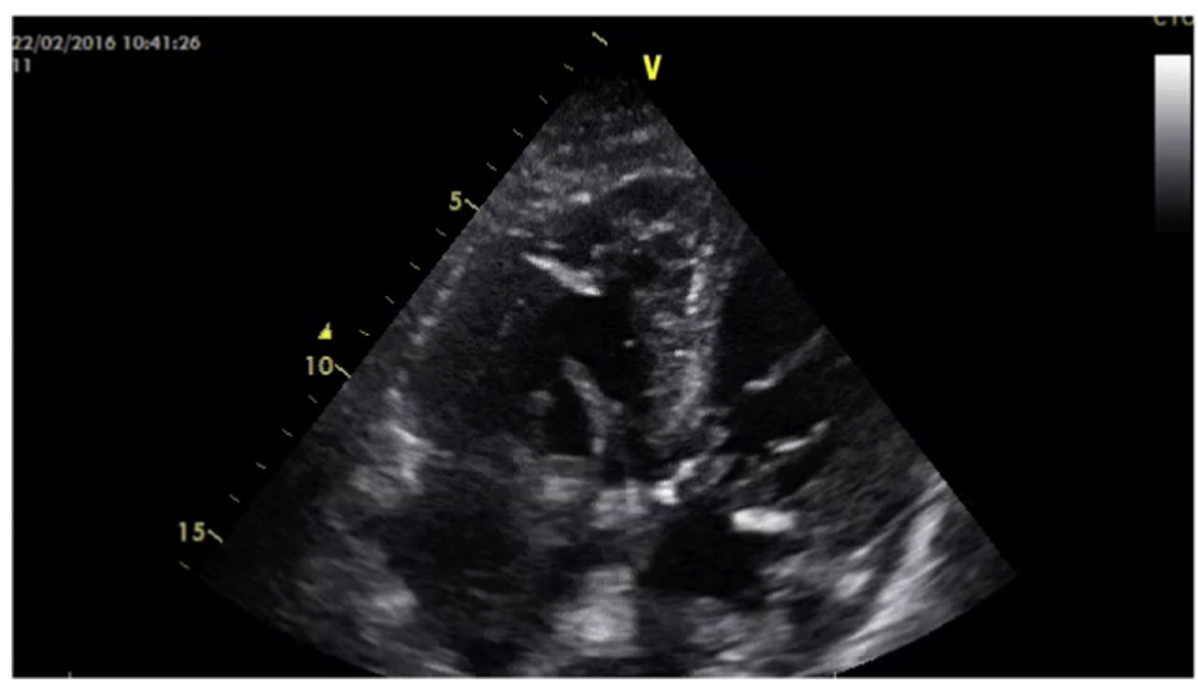

Fig. 1 Right heart thrombi.

\footnotetext{
* Corresponding author.

E-mail address: sylvain.aguilhon@gmail.com (S. Aguilhon).
} 
fast cardiac echography revealed a bulky mass on the right cavities (Fig. 1). An acute pulmonary embolism was suspected and the patient was transferred in the intensive cardiological care unit. A novel echocardiography confirmed the presence of a mass in to the right cavities. The right cavities were dilated ( $41 \mathrm{~mm}$ in medium ventricle) and moderately hypokinetic (TAPSE at $15 \mathrm{~mm}$ and $\mathrm{S}$ wave at $9 \mathrm{~cm} / \mathrm{s}$ ). The pulmonary pressures were estimated at $55 \mathrm{~mm} \mathrm{Hg}$ with a dilatation of the inferior vena cava. The left ventricle was not dilated and not hypertrophied. The left ventricular function was preserved. There was no significant left valvulopathy and the pericardium was dry. The hypothesis of a massive pulmonary embolism appeared to be the most likely diagnosis but was impossible to confirm because of the contraindication for the pulmonary angioscanner (predialysis real function and unstable hemodynamics), or pulmonary scintigraphy of ventilation perfusion. This patient was potentially at high-risk of pulmonary embolism with a PESI score estimated at 178 (class V). The patient presented no major contraindication of thrombolysis but several minor: age $>75$ years, antecedent of stroke [1].

After collegial discussion and after dialogue with the patient, the family and the general practitioner, thrombolysis was decided (acteplace, $100 \mathrm{mg}$ over $2 \mathrm{~h}$ ). Only a moderate epistaxis a few hours after the end of the thrombolysis was noticed.

A control of the echocardiography showed a complete regression of the thrombus.
The evolution during the hospitalization was rapidly good with early oral anticoagulant therapy and discharge at day 10 . Although the indication of thrombolysis is validated in the setting of a massive PE with arterial hypotension, its use in the setting of PE without hemodynamic instability is discussed [2]. The thrombolysis must be considered with case by case by taking count of the hemorrhagic risk. Here, the echocardiography urged to propose thrombolysis: the large highly mobile free-floating right/ventricular thrombus is life-threatening. Age or comorbidities should advocate also for this option, but are often considered as risk factors for complications. Cautious balance has to be evaluated.

\section{Conflict of interest}

The authors declare that there are no conflict of interest.

\section{References}

[1] C. Kearon, E.A. Akl, A.J. Comerota, P. Prandoni, H. Bounameaux, S.Z. Goldhaber, et al. Antithrombotic therapy for VTE disease: antithrombotic therapy and prevention of thrombosis, American College of Chest Physicians Evidence-Based Clinical Practice Guidelines, nineth ed., Chest. févr, Vol. 141(2 Suppl.), 2012, pp. e419S-e496S.

[2] G. Meyer, E. Vicaut, T. Danays, G. Agnelli, C. Becattini, J. Beyer-Westendorf, et al., Fibrinolysis for patients with intermediate-risk pulmonary embolism, N. Engl. J. Med. 370 (15) (2014) 1402-1411 (10). 